\title{
Hubungan Kreativitas Dengan Kecerdasan Emosional Pada Siswa MTs Islamiyah Ciputat Banten
}

\author{
Abdul Aziz Ridha*1 \\ Universitas Muhammadiyah Makassar*1 \\ *1email: abdulazizridha@unismuh.ac.id
}

\begin{abstract}
This research aims to find and analyze the relationship of creativity with the emotional intelligence in the students MTs Islamiyyah Ciputat, Banten. In this study used quantitative methods. The population in this study amounted to 115 while a sample of 52 students and schoolgirls by using sampling techniques nonprobability sampling technique with type purposive sampling. In this study, data collection was conducted by sharing questionnaire poll for creativity variables and emotional intelligence variables. The results of the research that has been done first, there is a relationship between the creativity of students with the emotional intelligence of students, in the students of class VIII MTs Islamiyyah Ciputat. Secondly, The size of creativity of students with the emotional intelligence of class VIII MTs Islamiyyah Ciputat students, obtained the correlation coefficient $r_{x y}=0.27$, with contributions, $07.29 \%$, with significant student creativity variables and students emotional intelligence variables of 2.25. Degrees of freedom (df) 50 are consulted with $t_{\text {tabel }}$ Significance of $5 \%$ by 2.00 . Thus obtained $t_{h} \geq t_{t}(0.25>2.00)$ at a level of significance $5 \%$ then $\mathrm{Ha}$ accepted and Ho was rejected. This indicates there is a low relationship between the creativity of students with emotional intelligence students, in the students of class VIII MTs Islamiyyah Ciputat, Tangsel, Banten. Thus that there is a relationship between creativity and emotional intelligence.
\end{abstract}

Keywords: Creativity and Emotional Intelligence.
Artikel Info

Received:

26 November 2019

Revised:

23 December 2019

Accepted:

09 February 2020

Published:

02 Juni 2020

\section{Abstrak}

Penelitian ini bertujuan untuk menemukan serta
menganalisis hubungan kreativitas dengan kecerdasan

Copyright $\odot$ 2020. Intiqad: Jurnal Agama dan Pendidikan Islam. This is an open acces article under the CC-BY-SA lisence (https://creativecommons.org/licenses/by-sa/4.0/). 
emosional pada siswa MTs Islamiyyah Ciputat, Banten. Dalam penelitian ini digunakan metode kuantitatif. Populasi pada penelitian yang dilakukan ini berjumlah 115 sedangkan sampel sebanyak 52 siswa dan siswi dengan menggunakn teknik sampling teknik nonprobability sampling dengan jenis purposive sampling. Pada penelitian ini dilakukan pengumpulan data dengan membagikan angket kuesioner untuk variabel kreativitas dan variabel kecerdasan emosional. Hasil penelitian yang telah dilakukan Pertama, terdapat hubungan antara kreatifitas siswa dengan kecerdasan emosional siswa, pada siswa kelas VIII MTs Islamiyyah Ciputat. Kedua, Besaran hubungan kreatifitas siswa dengan kecerdasan emosional siswa kelas VIII MTs Islamiyyah Ciputat, diperoleh koefisien korelasi $r_{x y}=0,27$, dengan kontribusi, 07,29\%, dengan signifikan variabel kreativitas siswa dan variabel kecerdasan emosional siswa sebesar 2,25. Derajat kebebasan (df) 50 dikonsultasikan dengan $t_{\text {tabel }}$ pada taraf signifikansi 5\% sebesar 2,00. Sehingga diperoleh $t_{h}$ $\geq t_{t} \quad(0,25>2,00)$ pada taraf signifikansi $5 \%$ maka $\mathrm{Ha}$ diterima dan Ho ditolak. Hal ini menunjukkan terdapat hubungan yang rendah antara kreatifitas siswa dengan kecerdasan emosioanal siswa, pada siswa kelas VIII MTs Islamiyyah Ciputat, Tangsel, Banten. Dengan demikian bahwa ada hubungan antar kreativitas dengan kecerdasan emosional.

Keywords: Kreativitas dan Kecerdasan Emosional.

\section{A. Pendahuuan}

Manusia adalah makhluk ciptaan Tuhan yang secara biologis berawal dari fisik yang lemah (janin) kemudian tumbuh menjadi bayi, menjadi remaja, hingga menjadi dewasa, kemudian memasuki masa tua yang membuatnya kembali menjadi lemah dan diakhiri dengan kematian. Namun di luar itu, manusia hidup dengan memiliki banyak potensi. Berbagai kelebihan dimiliki manusia sehingga memungkinkan dirinya untuk meningkatkan kualitas sumber daya dirinya. Manusia juga dibekali dengan berbagai kecerdesan, salah satunya kecerdasan emosional. 
ISSN 1979-9950 (print) || ISSN 2598-0033 (online), http://jurnal.umsu.ac.id/index.php/intiqad

DOI: 10.30596/intiqad.v\%vi\%i.3785

Vol. 12, No. 1 (June 2020)

Kecerdasan emosional merupakan kemampuan untuk mengenali diri (menyadari kesadaran diri), mengendalikan diri yang spontan, menumbuhkan rasa empati terhadap orang lain melalui komunikasi sesama individu, selain itu juga kecerdasan emosional berperan penting terhadap memotivasi diri terhadap hal yang positif, serta melihat aspek pengalaman, perasaan, pikiran, persepsi serta tingkah laku seseorang (Herwono, 2005).

Berbagai faktor memengaruhi perkembangan kecerdasan emosional, baik eksternal maupun internal. Faktor eksternal memiliki peranan penting dalam mempengaruhi perkembangan kecerdasan emosional anak kondisi lingkungan seperti keluarga, dan orang tua sebagai figur terdekat anak, sedangkan faktor internal dipengaruhi oleh kondisi anak itu sendiri.

Pendidikan di sekolah umumnya lebih memperhatikan aspek kecerdasan berfikir serta logika atau yang dikenal dengan istilah kecerdasan intelektual (Bahasa Inggris: intelligence quotien, disingkat IQ). Aspek kecerdasan emosional maupun aspek-aspek lain masih kerap dilupakan. Guru di dalam kelas juga lebih berorientasi pada penyampaian materi secara tuntas, tanpa melihat materi yang disampaikan. Hal itu memberi dampak pada perubahan perilaku dan mental ke arah yang positif. Padahal menurut Goleman kesuksesan hidup seseorang tidak ditentukan oleh intelektual karena intelektual maksimal berkontribusi sebanyak 20\% dalam hidup seseorang, $80 \%$ lainnya dipengaruhi hal lainnya, diantaranya kecerdasan emosional dimana kemampuan individu manusia dalam bekerja sama tarhadap individu lainnya, menumbuhkan sikap empati, mengontrol suasana emosi hati, mengatasi frustasi diri, mengkondisikan diri sendiri, serta mampu mengontrol emosi dengan baik (Goleman, 1996).

Jadi jika ingin meraih kesuksesan bukan hanya mementingkan kecerdasan intelektual akan tetapi perlu juga kecerdasan yang lainnya salah satunya kecerdasan emosional.

Untuk mengembangkan diri, manusia bukan hanya mengandalkan 
ISSN 1979-9950 (print) || ISSN 2598-0033 (online), http://jurnal.umsu.ac.id/index.php/intiqad

DOI: 10.30596/intiqad.v\%vi\%i.3785

Vol. 12, No. 1 (June 2020)

kecerdasan-kecerdasan yang dia miliki, akan tetapi manusia juga harus memiliki kreativitas dimana kreativitas tersebut mampu membantu dalam mengembangkan diri.

Menurut Yoris Sebastian kreativitas merupakan suatu kemampuan atau skill yang dimiliki oleh siapapun yang dapat diperoleh melalui kebiasaan dan latihan (Sebastian, 2010).

Kreativitas tumbuh dengan sendirinya selama manusia meningkatkan kualitas dirinya melalui kebiasaan dan latihan lalu apakah ada hubungan kreativitas dengan kecerdasan emosional?

Tujuan dalam penelitian ini adalah untuk menemukan dan membahas hubungan kreativitas dengan kecerdasan emosional pada siswa MTs Islamiyyah Ciputat, Banten.

\section{B. Landasan Teori}

1. Kreativitas

\section{a. Pengertian Kreativitas} Memahami konsep kreativitas dapat diawali dari memahami arti kamusnya. Di dalam Kamus Besar Bahasa Indonesia, kreativitas berarti mampu menciptakan sesuatu atau mengkreasikan sesuatu. Namun pengertian ciptaan dari hasil kreativitas yaitu memodifikasi bermacam-macam ide dan karya untuk menjadi hal yang baru, jadi cipataan tersebut bukanlah hal yang baru (Purwanto, 2005).

Dari pengertian di atas dapat dipahami bahwa kreativitas bukanlah sesuatu yang baru melainkan sebuah karya dari kombinasi dan modifikasi dari sesuatu yang telah menjadi hal yang baru.

Kreativitas memiliki banyak pengertian yang populer diantaranya ada yang mendefinisikan kreativitas pada empat bagian yakni Person (pribadi), Process (proses), Press (pendorong), dan Product (hasil). Kreativitas dari segi person (pribadi) menunjukkan bahwa setiap individu memeliki potensi untuk kreatif. Kreativitas sebagai suatu process (proses) dimana setiap individu dalam menghadapi sebuah masalah mampu menemukan bentuk pemikiran yang baru, mampu menjawab permasalahan, serta mampu menyelesaikan masalah dengan metode yang baru. Kreativitas 


\section{INTIQAD: JURNAL AGAMA DAN PENDIDIKAN ISLAM}

ISSN 1979-9950 (print) || ISSN 2598-0033 (online), http://jurnal.umsu.ac.id/index.php/intiqad

DOI: 10.30596/intiqad.v\%vi\%i.3785

Vol. 12, No. 1 (June 2020)

sebagai press (pendorong) dimana individu memiliki motivasi dan keinginan yang tinggi dalam mengkreasikan sesuatu. Dan kreativitas dari sisi product (hasil) yaitu individu yang berhasil menciptakan sesuatu yang unik dari dirinya hasil dari bersosialisasi di daerah sekitarnya (Satiadarma \& Wawuru, 2003).

Berdasarkan pengertian di atas bahwa kreativitas mencakup pada empat dimensi diantaranya, kepribadian, proses kreativitas, pendorong kreativitas serta hasil. Dari empat dimensi inilah kreativitas bisa muncul dari diri seseorang.

Adapun definisi tentang kreativitas menurut para ahli:

James J. Gallagher dalam Rahmawati mengatakan bahwa, "kreativitas itu ketika individu melakukan proses mental baik itu berupa produk atau gagasan yang baru atau melekatkan pada dirinya kedua hal tersebut" (Rahmawati \& Kurniati, 2010).

Sedangkan Menurut Utami Munandar, "kreativitas yaitu dimana seseorang mampu menciptakan kolaborasi yang baru sesuai unsur-unsur, data, serta informasi yang didapatkan" (Munandar, 1999).

Dari pendapat para ahli yang dikemukan sebelumnya dapat ambil kesimpulan bahwa sesungguhnya kreativitas itu membuat kolaborasi baru dari data yang sudah ada.

Kreativitas tersusun dari hal yang tidak sederhana, selain itu kreativitas dapat bertambah karena beberapa factor; mampu berkreasi, mampu menyusun kembali, mampu memperbaharui, membuat hubungan yang baru, cepat tanggap terhadap sesuatu yang terjadi di sekitarnya, fleksibel terhadap sesuatu, berekspresi sesuai apa yang disukai, serta mampu menghadapi permasalahanpermasalan yang terjadi di lingkungannya (Al-Khalili, 2005).

\section{b. Ciri-ciri Kreativitas}

Kreativitas memiliki ciri-ciri diantaranya kognitif yang meliputi fleksibilitas, orisinilitas, dan elaborasi serta non kognitif yang terdiri dari motivasi, sikap, serta kepribadian yang kreatif. 
ISSN 1979-9950 (print) || ISSN 2598-0033 (online), http://jurnal.umsu.ac.id/index.php/intiqad

DOI: 10.30596/intiqad.v\%vi\%i.3785

Vol. 12, No. 1 (June 2020)

Hamzah B. Uno menyebutkan beberapa ciri seorang yang memiliki kreativitas, yaitu: 1) Lihat masalah dari berbagai sisi, 2) Memiliki kemauan terhadap sesuatu yang tinggi, 3) Tidak menolak terhadap hal-hal yang baru, 4) Menyukai tugas yang penuh tantangan, 5) Berpikir luas, serta tidak mencela hasil orang lain (Uno, 2008).

\section{c. Faktor Pendukung dan}

\section{Penghambat dalam Perkembangan}

\section{Kreativitas}

Menurut Yeni Rachmawati dan Euis Kurniati, ada beberapa faktor yang mampu mempengaruhi pada perkembangan kreativitas, yaitu:

\section{1) Mental.}

Anak yang kreatif cenderung menyukai tantangan, oleh karena itu potensi kreatif dapat dikembangkan melalui rangsangan atau stimulus yang dapat merangsang perkembangan kreativitas dengan cara memberikan mereka suatu permasalahan yang dijadikan sebagai stimulus bersifat mendidik dan sesuai dengan kemampuannya.

\section{2) Lingkungan sekitar dan iklim}

Lingkungan sangat berpengaruh besar terhadap perkembangan kreativitas. Jika seorang anak tinggal dalam lingkungan yang menjemukan, maka tanpa disandari kereativitas yang dia miliki akan stagnan bahkan cenderung hilang.

\section{3) Peran guru}

Pendidik dapat berperan aktif dalam menciptakan suasana yang menyenangkan dalam lingkungan belajar dengan cara menghargai dan menghormati keberadaan siswa sebagai individu sebagaimana adanya, memberi kebebasan dan menjauhi sikap otoriter dalam memupuk potensi kreativitas yang ada pada diri setiap siswa.

4) Peran guru dan tanggung jawab orang tua

Orang tua pada dasarnya terlibat langsung dalam pertumbuhan kreativitas anak, dimana orang tua umumnya senantiasa bersama anakanaknya dalam segala situasi, sehingga memiliki kemampuan untuk mengetahui bakat dan minat apa yang 
ISSN 1979-9950 (print) || ISSN 2598-0033 (online), http://jurnal.umsu.ac.id/index.php/intiqad

DOI: 10.30596/intiqad.v\%vi\%i.3785

Vol. 12, No. 1 (June 2020)

dimiliki anaknya, serta memberikan motivasi dan dorongan agar kreativitas anak berkembang dengan baik.

Jadi faktor pendukung dalam tumbuhnya kreativitas siswa diantaranya mental, lingkungan sekitar dan iklim, guru di sekolah dan orang tua. Keempat faktor ini sangat mempengaruhi tumbuh kembangnya kreativitas siswa.

Faktor penghambat dalam perkembangan Kreativitas diantaranya (Rahmawati S. , 2001):

Hambatan Fisik tidak jarang dirasakan oleh mereka yang mengalami kekurangan/cacat fisik, meski pada kenyataannya tidak semua orang yang cacat fisik tidak dapat berkreasi. Ada segelintir orang yang cacat tetapi mampu berbicara lebih banyak dengan kreasi yang diciptakannya dan mampu mengalahkan orang yang normal secara fisik. Karena mereka memiliki motivasi yang sangat besar dibanding dengan siapapun.

Hambatan informasi kreativitas berarti menggunakan kemampuan berfikir yang dimiliki untuk menciptakan hal-hal yang berdaya guna, dan hal itu hanya dapat terjadi jika seseorang memiliki pengetahuan atau informasi yang cukup sebagai bekal dalam kehidupannya.

Hambatan sosial memiliki cakupan yang lebih luas dibandingkan dengan yang lainnya, karena hal ini berkaitan dengan interaksi antara anak dengan orang di sekitarnya. Baik itu dengan keluarga, orang tua, guru maupun lingkungan tempat ia tinggal. Dalam proses interaksi tersebut tentunya banyak pula hal-hal yang dapat menekan tumbuhnya kreativitas anak terutama oleh orang tua yang merupakan orang terdekat dalam kehidupannya.

Demikianlah faktor-faktor pada kreativitas siswa, diantaranya hambatan fisik, hambatan informasi, dan hambatan sosial

\section{d. Manfaat Kreativitas Bagi Siswa}

Kegiatan pembelajaran merupakan proses, dan manfaatnya tidak dirasakan secara langsung oleh peserta didik melainkan baru akan dirasakan dikemudian hari. Tanpa bermaksud mengecilkan fungsi pendidikan dalam 
ISSN 1979-9950 (print) || ISSN 2598-0033 (online), http://jurnal.umsu.ac.id/index.php/intiqad

DOI: 10.30596/intiqad.v\%vi\%i.3785

Vol. 12, No. 1 (June 2020)

ranah kognitif, bahwa masyarakat dan dunia kerja terlihat sukses dan hidup bahagia ternyata bukan mereka yang berprestasi tinggi di bangku sekolah, melainkan mereka yang berhasil menggunakan potensi kreatifnya dengan baik, berani mengambil resiko dan mampu memecahkan permasalahannya (Munandar, 1999).

Tidak sedikit para pengusaha sukses dalam bidangnya dan ternyata hanya lulusan Sekolah Dasar atau SMP, mereka tidak dapat mengandalkan ijazah yang dimiliki, tetapi mereka mampu mengoptimalkan potensi kreatif yang dimiliki menjadi sesuatu yang sangat berharga dan berdaya guna.

Siswa yang kreatif akan lebih siap menghadapi tantangan zaman dibandingkan siswa yang kurang kreatif. Kita telah melihat siswa-siswi SMK yang telah berhasil berkarya membuat mobil atau membuat penemuanpenemuan berharga lainnya, bahkan kita sering mendengar bahwa siswa-siswi SMK mendapat nobel atau penghargaan atas karya-karya yang berhasil mereka buat.
Itu semua mereka capai selain mendapat bimbingan dari guru dan orang tua dalam mengembangkan potensi kreatif, tetapi juga dari motif instrinsik siswa yang lebih besar dan dari kesadaran akan pentingnya kreativitas yang mereka miliki. Setelah mereka menyelesaikan pendidikannya, masa depan mereka akan lebih terjamin dan terarah yaitu untuk mengembangkan potensi yang dimilikinya itu. Mereka akan merasa lebih puas dengan kemampuan sendiri sehingga termotivasi untuk berbuat yang lebih baik.

Jadi secara mendasar bahwa terkadang manfaat kreativitas bagi siswa dirasakan ketika selesai Sekolah atau lulus sekolah, meskipun pada saat sekolah kreativitas itu bisa tumbuh dengan sendirinya, dimana dengan kreativitas yang dimiliki mampu menunjang dalam mengikuti kegiatan di sekolah bahkan mampu berprestasi karena memiliki kreativitas yang tinggi. 
ISSN 1979-9950 (print) || ISSN 2598-0033 (online), http://jurnal.umsu.ac.id/index.php/intiqad

DOI: 10.30596/intiqad.v\%vi\%i.3785

Vol. 12, No. 1 (June 2020)

2. Kecerdasan Emosional

a. Pengertian

Emosional

M. Alisuf Sabri

menyatakan "Kecerdasan seseorang dapat dilihat ketika dia bertindak, karena kecerdasan merupakan kata kerja. Sehingga jika seseorang melakukan aktifitas akan terlihat apakah orang tersebut memiliki kecerdasan yang baik atau tidak. Jika kecerdasannya baik maka hasil pekerjaannya tentu baik, jika kecerdasannya kurang hasil pekerjaannya juga kurang baik.

W.J.S Poerwadarminta

mendefinisikan "Secara mendasar kecerdasan itu dimana perkembangan akal budinya positif, dalam berfikir senantiasa selalu pandai dan befikiran terbuka, selain itu cerdas juga perkembangan fisiknya sehat dan baik dalam tumbuh kembangnya".

Gardner membagi kecerdasan pada tujuh bagian yaitu, "cerdas dalam bermusik, Cerdas dalam berpikir matematik, cerdas dalam bahasa, cerdas dalam penglihatan, cerdas dalam olah tubuh, cerdas dalam mengamati orang lain, dan kecerdasan dalam mengamati diri sendiri” (Rose \& Nicholl, 1993).

Daniel Goleman dalam Rose mengatakan emosi adalah kondisi dimana mental atau emosi yang meluapluap dikarenakan pergolakan pikiran, nafsu, dan perasaan (Uno, 2008).

Selain itu juga emosi adalah respon terhadap apa yang terjadi yang ditandai dengan perubahan pada diri dalam memberikan tanggapan terhadap apa yang yang sedang disaksikan, hal ini berarti bahwa terjadi perubahan emosi atas kejadian yang telah disaksikan (Uno, 2008).

Daniel Goleman mengungkapan bahwa kecerdasan emosional memiliki macam-macam pengertian:

Kecerdasan dalam emosional diperlukan dalam pengendalian diri, pada waktu-waktu tertentu sikap ramah terhadap apa yang terjadi tidak diperlukan, tetapi sikap yang tegas terhadap apa yang terjadi ketika tidak sesuai dengan hati nurani terkadang diperlukan, karena mengungkapkan kebenaran perlu dilakukan. Kecerdasan emosional diperlukan dalam mengelola 


\section{INTIQAD: JURNAL AGAMA DAN PENDIDIKAN ISLAM}

ISSN 1979-9950 (print) || ISSN 2598-0033 (online), http://jurnal.umsu.ac.id/index.php/intiqad DOI: 10.30596/intiqad.v\%vi\%i.3785

Vol. 12, No. 1 (June 2020)

emosi yang terjadi pada diri, hal ini diperlukan agar emosi dapat terolah dengan baik dan diekspresikan dengan baik sesuai kondisi yang sedang dialami, sehingga setiap inidividu mampu bersama-sama dalam bekerja sesuai dengan tujuan yang akan dicapai. Lebih lanjut Kecerdasan emosional berarti kepandaian, dan kepatutan individu dalam mengelola pribadinya, sehingga memudahkan dalam adaptasi pada lingkungan sekitar serta mampu bekerja sama dengan baik terhadap siapapun (Uno, 2008).

Kecerdasan emosional adalah suatu proses dalam mengerti diri sendiri, mengendalikan pribadi, memotivasi, serta mampu memahami lingkungan sekitar yang terjadi sehingga mampu memberikan respon terhadap apa yang terjadi di sekitarnya (Herwono, 2005).

Dari beberapa pengertian tersebut disimpulkan bahwa kemampuan dalam mengolah diri dalam berbagai keadaan serta mampu memposisikan diri dalam berbagai situasi adalah kecerdasan emosional.

\section{b. Indikator Kecerdasan Emosional}

Untuk mengukur atau mempelajari Kecerdasan emosional perlu diketahui indikator-indikatornya, diantaranya yaitu: Pertama, mengenali emosi diri dimana mengetahui sifat dasar yang ada pada diri, apakah kita termasuk orang yang mudah terselut emosi atau tidak, sehingga dengan mengenali emosi diri memudahkan kita dalam bersikap. Kedua, mengelola emosi yaitu mampu mengkodisikan diri sehingga dapat mengungkapkan isi hati dengan baik. Ketiga, Motivasi diri sendiri dimana mampu menuntun diri untuk selalu semangat dalam setiap keadaan tidak mudah tepuruk terhadap sesuatu yang tidak diinginkan sehingga mampu mengambil inisiatif yang efektif dalam bertindak. Keempat, empati; mengerti apa yang dialami oleh orang lain, sehingga memiliki kemampuan ini masing-masing orang saling memiliki keterikatan satu sama lain, sikap saling peduli satu sama lain sehingga menimbulkan sikap sosial yang positif.

Jadi ada empat indikator dalam kecerdasan emosional diantaranya; 


\section{INTIQAD: JURNAL AGAMA DAN PENDIDIKAN ISLAM}

ISSN 1979-9950 (print) || ISSN 2598-0033 (online), http://jurnal.umsu.ac.id/index.php/intiqad

DOI: 10.30596/intiqad.v\%vi\%i.3785

Vol. 12, No. 1 (June 2020)

mengenali emosi diri sendiri, mengelola emosi diri, motivasi diri dan empati.

\section{c. Pengembangan}

\section{Kecerdasan}

\section{Emosional}

Berbicara tentang emosi manusia Alquran dan Hadis juga membahas hal tersebut. Alquran dan Hadis mengungkapkan emosi dasar manusia dengan bahasa yang indah, bahagia, sedih, sabar, marah, takut diungkapkan dengan jelas. Emosi lainnya yang ada pada individu manusia seperti kesombongan, berbangga diri, cinta, kedengkian, serta benci. Alquran dan Hadis membahasnya dengan penjelasan yang sangat baik (Hasan, 2008).

Setiap orang mampu mengontrol emosinya, tentunya dengan melalui dua cara yaitu menirukan apa yang ada di sekitarnya atau membiasakan diri baik itu positif dan negatif. Orang tua serta guru memiliki peranan penting dalam membina emosi anak. Jika dalam lingkungan keluarga masing-masing memiliki emosi yang senantiasa positif maka anak cenderung memiliki emosi yang positif dan stabil. Sebaliknya, jika orang tua terbiasa dengan prilaku emosi yang negatif dalam mengekspresikan diri seperti sering marah, mudah putus asa, tidak bisa menahan atau mengontrol emosi dalam menghadapi suatu permasalahan, maka perkembangan emosi anak cenderung mengarah ke halhal negatif sehingga perkembangan emosinya menjadi kurang baik dan tidak sehat (Yusuf \& Sugandhi, 2011).

John Gottman dalam Nggermanto merumuskan: ada lima langkah dalam mengembangkan kecerdasan emosional (EQ) (Nggermanto, 2011):

Langkah pertama: orang tua harus menyadari sikap emosional pada anaknya, dan orang tua juga harus memahami emosi yang dominan pada anaknya, sehingga dengan demikian orang tua siap menjadi pelatih atau terapis bagi anaknya agar emosinya cenderung mengarah ke hal yang positif.

\section{Langkah Kedua: menangani} emosi dengan baik dalam segala kondisi, ketika seorang anak mendapatkan hal yang tidak dia inginkan seperti nilai yang tidak bagus, mendapat perlakuan buruk dari teman, serta pengalaman- 


\section{INTIQAD: JURNAL AGAMA DAN PENDIDIKAN ISLAM}

ISSN 1979-9950 (print) || ISSN 2598-0033 (online), http://jurnal.umsu.ac.id/index.php/intiqad DOI: 10.30596/intiqad.v\%vi\%i.3785

Vol. 12, No. 1 (June 2020)

pengalaman negatif lainnya. Keadaan ini sangat berpeluang bagi anak untuk mengelola emosinya sehingga dalam kondisi yang tidak disukai emosi anak tetap stabil.

Langkah Ketiga: sikap empati melalui mata dan pendengaran anak. Dengan adanya empati anak mampu mengamati emosi-emosi seseorang sehingga anak bisa membedakan mana emosi yang positif dan emosi yang negatif.

Langkah Keempat: Setiap anak tentunya dalam kehidupannya pasti dihadapkan oleh masalah. Orang tua dan guru sebagai orang yang terdekat harus membantu dalam memecahkan masalah yang dihadapi oleh anak, mulai dari merumuskan masalah, batasan masalah, proses pemecahan masalah, dan mengevaluasi masalah. Dengan membantunya tentu memudahkan anak dalam memecahkan masalahnya, sehingga emosinya berkembang dengan baik.

Langkah Kelima: orang tua dan guru harus menjadi teladan, karena dengan memberikan contoh perbuatan yang baik prilaku serta perbuatan anakanak akan berubah ke arah yang positif tanpa harus banyak berkata-kata. Keteladanan juga menjadi metode yang efektif dalam mengembangkan emosi anak, dan anak pada umumnya lebih senang mengikuti tindakan positif yang dilakukan dibandingkan dengan mendengarkan ceramah yang terkadang membuat mereka bosan, terlebih lagi jika ucapan tidak sesuai dengan perkataan.

Jadi dalam mengembangkan kecerdasan emosional dapat dilakukan dalam lima langkah, dimana dengan pengembangan tersebut menjadikan kecerdasan emosional siswa menjadi lebih baik.

\section{d. Wilayah Kecerdasan Emosional}

Mayer dan Salovey dalam Goleman mengungkapkan ada lima aspek kecerdasan pribadi dalam kecerdasan emosional (Goleman, 1996).

Pertama; Mengenali emosi diri. Secara mendasar, manusia mengerti emosi yang dominan pada dirinya. Jika individu mengerti dengan baik emosi yang dominan pada dirinya maka secara 
ISSN 1979-9950 (print) || ISSN 2598-0033 (online), http://jurnal.umsu.ac.id/index.php/intiqad

DOI: 10.30596/intiqad.v\%vi\%i.3785

Vol. 12, No. 1 (June 2020)

langsung individu tersebut memiliki kecerdasan emosional yang baik, sehingga individu tersebut bisa mengendalikan emosi dirinya dengan baik, sehingga emosinya bisa terkontrol dengan positif.

Kedua; Mengelola emosi. Setiap manusia pasti memiliki emosi pada dirinya, sehingga setiap manusia harus memiliki pengolaan emosi yang baik. Dengan pengolaan emosi yang baik setiap individu bisa mengekspresikan emosinya dengan tepat.

Ketiga; Memotivasi diri sendiri. Dalam melakukan aktifitas apapun seeorang membutuhkan dorongan dari dalam dirinya atau umumnya disebut motivasi dari diri sendiri. Dengan memiliki motivasi dari dirinya, seseorang akan selalu bergairah atau semangat dalam melakukan aktifitas. Sehingga apapun yang dilakukan akan terasa mudah. Dan tujuan yang ingin dicapai akan mudah didapatkan.

Keempat: Mengenali emosi orang lain. Kecerdasan emosional seseorang bukan hanya dilihat dari seberapa pandai seseorang itu dalam mengelola emosi dirinya, akan tetapi dilihat juga seberapa cerdas seseorang tersebut dalam mengenali emosi orang lain terutama orang yang ada di dekatnya, baik itu rekan belajar ataupun rekan kerja. Dengan mengerti emosi orang lain maka akan menumbuhkan sikap empati satu sama lain.

Kelima; Berkomunikasi dengan orang-orang sekitarnya. Dalam kehidupan bersosial, berinteraksi dengan orang lain tentu tidak bisa dilepaskan. Agar komunikasi terjalin dengan baik maka dibutuhkan kecerdasan dalam berkomunikasi dengan orang lain. Sehingga jika sikap ini terbangun maka masing-masing inidividu akan memiliki sikap saling peduli dan saling kasih sayang.

\section{Metodologi}

Dalam penelitian ini, populasinya adalah siswa dan siswi kelas VIII MTs Islamiyyah Ciputat, Banten, sebanyak 115 siswa dan siswi.

Dalam penelitian ini penulis menetapkan sampel sebanyak 52 siswa dimana teknik pengambilan sampel ini 
ISSN 1979-9950 (print) || ISSN 2598-0033 (online), http://jurnal.umsu.ac.id/index.php/intiqad DOI: 10.30596/intiqad.v\%vi\%i.3785

Vol. 12, No. 1 (June 2020)

menggunakan rumus Slovin dengan teknik nonprobability sampling dengan jenis purposive sampling.

Dalam memperoleh data peneliti mengambil data berdasarkan:

1. Observasi dimana peneliti mengamati langsung di lapangan untuk menyaksikan kondisi dan situasi lokasi objek yang diteliti.

2. Angket, dalam penelitian ini penulis menyebarkan angket berkaitan dengan kecerdasan emosional dan kreativitas.

\section{Hasil Penelitian}

Hasil temuan peneliti dalam mencari apakah hipotesis diterima atau tidak, dan ternyata hipotesis yang diajukan diterima atau menandakan ada pengaruh signifikan yaitu "terdapat hubungan antara kreativitas siswa dengan kecerdasan emosional siswa pada siswa dan siswi kelas VIII MTs Islamiyyah Ciputat. Hal ini berarti bahwa semakin baik kreativitas siswa kelas VIII MTs Islamiyyah, Ciputat, maka semakin baik pula kecerdasan emosional siswa dan siswi kelas VIII MTs Islamiyyah, Ciputat.

Temuan hipotesis tersebut dilakukan melalui tahap-tahap berikut:

Tahap pertama, peneliti mengumpulkan data kreativitas siswa kelas VIII MTs Islamiyyah Ciputat dan Kecerdasan emosional melaluli tes angket yang diadakan peneliti kepada 52 siswa dan siswi kelas VIII MTs Islamiyyah, Ciputat.

Tahap kedua, setelah mengumpulkan data kemudian diolah serta dianalisis dengan memakai analisis korelasi Pearson Produt Moment. Lalu data diinput ke dalam tabel distribusi frekuensi kreatifitas siswa dan tabel distribusi frekuensi kecerdasan emosional.

Tahap ketiga, memastikan kontribusi lalu mengujinya apakah kreativitas (X) dan kecerdasan emosional (Y) ada hubungan yang positif ataukah hanya kebetulan. Selain itu juga apakah ada korelasi dengan uji $\mathrm{t}$ dimana dengan mencocokkan nilai t dari $t_{\text {tabel }}$ yang didapatkan. 
ISSN 1979-9950 (print) || ISSN 2598-0033 (online), http://jurnal.umsu.ac.id/index.php/intiqad DOI: 10.30596/intiqad.v\%vi\%i.3785

Vol. 12, No. 1 (June 2020)

Sesuai dengan tahapan-tahapan yang telah dilakukan didapatkan hasil nilai dari masing-masing variabel yaitu:

1. Variabel $\mathrm{X}$ diketahui bahwa mean dari frekuensi kreativitas siswa kelas VIII MTs Islamiyyah Ciputat termasuk kategori sedang karena diposisi interval $48-90$.

2. Variabel Y diketahui bahwa mean dari frekuensi kecerdasan emosional siswa kelas VIII MTs Islamiyyah Ciputat, termasuk kategori cukup karena di posisi interval $63-96$.

3. Mencari derajat hubungan antara variabel $\mathrm{X}$ dan $\mathrm{Y}$, dari hasil perhitungan diketahui hubungan yang dimiliki rendah, dengan $r_{x y}=$ 0,27 artinya semakin baik kreativitas siswa maka kecerdasan emosional siswa juga bagus.

4. Lalu mencari kontribusi serta mengujinya apakah terdapat hubungan antara krearivitas (X) dan kecerdasan emosional (Y) ataukah bertepatan saja serta dilakukan signifikansi dengan uji t. hasilnya diperolehlah uji t sebesar 2,22.
5. Setelah itu mencocokkan nilai $t$ yang telah didapatkan dengan $t_{\text {tabel. }}$. Dengan $t_{\text {tabel }} 5 \%=2,00$ dari hasil perhitungan diperoleh $t_{h} \geq$ $t_{t}(0,25>2,00)$.

Dari uraian tahapan-tahapan yang telah dilakukan dalam di atas, bahwa kreatifitas siswa memiliki kontribusi terhadap kecerdasan emosional siswa, sehingga kreativitas siswa memiliki pengaruh terhadap kecerdasan emosional.

Sehingga apabila siswa mempunya kreativitas yang bagus, maka tingkat kecerdasan emosional siswa tersebut akan ikut bagus. Kebalikannya bila siswa memiliki kreativitas yang rendah bisa jadi tingkat kecerdasan emosional siswa tersebut juga rendah.

Dari hasil di atas dapat dilihat bahwa kreativitas memiliki kontribusi terhadap kecerdasan emosional siswa meski dalam penilitian ini yang dilakukan di MTs Islamiyyah Ciputat memiliki hubungan yang rendah tidak menutup kemungkinan jika faktor-faktor penghambat dalam perkembangan 


\section{INTIQAD: JURNAL AGAMA DAN PENDIDIKAN ISLAM}

ISSN 1979-9950 (print) || ISSN 2598-0033 (online), http://jurnal.umsu.ac.id/index.php/intiqad

DOI: 10.30596/intiqad.v\%vi\%i.3785

Vol. 12, No. 1 (June 2020)

kecerdasan emosional bisa di maka $\mathrm{Ha}$ diterima dan Ho ditolak. minimalisir.

\section{E. Simpulan}

Hasil temuan penelitian yang telah dikemukakan sebelumnya tentang hubungan antara kreatifitas siswa dengan kecerdasan emosional siswa pada siswa kelas VIII MTs Islamiyyah Ciputat. Banten, terdapat dua temuan: Pertama, Terdapat hubungan yang positif dan signifikan antara kreatifitas siswa dengan kecerdasan emosional siswa pada siswa kelas VIII MTs Islamiyyah Ciputat.

Kedua, Besarnya hubungan kreatifitas siswa dengan kecerdasan emosional siswa kelas VIII MTs Islamiyyah Ciputat, diperoleh koefisien korelasi $r_{x y}=0,27$, dengan kontribusi, 07,29\%, dengan signifikansi variabel kreativitas dan variabel kecerdasan emosional sebesar 2,25. Derajat kebebasan (df) 50 dikonsultasikan dengan $t_{\text {tabel }}$ pada taraf signifikansi $5 \%$ sebesar 2,00. Sehingga diperoleh $t_{h} \geq t_{t}$ $(0,25>2,00)$ pada taraf signifikansi $5 \%$

Al-Khalili, A. (2005). Mengembangkan Kreativitas Anak. Jakarta: Pustaka Al-Kaustar.

Goleman, D. (1996). Kecerdasan Emosional. (Hermayati, Trans.) Jakarta: Gramedia Pustaka Utama.

Hasan, A. B. (2008). Psikologi Perkembangan Islam. Jakarta: PT. Raja Grafindo Persada. 
ISSN 1979-9950 (print) || ISSN 2598-0033 (online), http://jurnal.umsu.ac.id/index.php/intiqad DOI: 10.30596/intiqad.v\%vi\%i.3785

Vol. 12, No. 1 (June 2020)

Herwono. (2005). Belajar Mengajar Berbasiskan Emosi. Jakarta: MLC.

Munandar, U. (1999). Mengembangkan dan Kreativitas Anak Sekolah. Jakarta: PT. Gramedia Widiasarana Indonesia.

Nggermanto, A. (2011). Quantum Quetient Cara Praktis Melejitkan $I Q, E Q, S Q$ yang Harmonis. Bandung: Nuansa.

Pembinaan, T. P., \& Pengembangan. (1988). Kamus Besar Bahasa Indonesia. Jakarta: Balai Pustaka.

Poerwadarminta, W. (1991). Kamus Umum Bahasa Indonesia. Jakarta: Balai Pustaka.

Purwanto. (2005). Kreativitas Berpikir Siswa dan Perilaku dalam Tes. Jurnal Pendidikan dan Kebudayaan, 11(55), 511.

Rahmawati, S. (2001). Mencetak Anak Cerdas dan Kreatif. Jakarta: Kompas.
Rahmawati, Y., \& Kurniati, E. (2010). Strategi Pengembangan Kreativitas Pada Anak Usia Taman Kanak-Kanak. Jakarta: Kencana.

Rose, C., \& Nicholl, M. J. (1993). Cara Belajar Cepat Abad XXI. (D. Ahimsa, Trans.)

Sabri, M. A. (1996). Psikologi Pendidikan. Jakarta: Pedoman Ilmu Jaya.

Satiadarma, M. P., \& Wawuru, F. E. (2003). Mendidik Kecerdasan. Jakarta: Pustaka Populer Obor.

Sebastian, Y. (2010). Oh My Goodnes! Buku Pintar Seorang Creative Junkies. Jakarta: PT. Gramedia Pustaka Utama.

Uno, H. B. (2008). Orientasi Baru Dalam Psikologi Pembelajaran. Jakarta: PT. Bumi Aksara.

Yusuf, S., \& Sugandhi, N. M. (2011). Perkembangan Peserta Didik. Jakarta: Rajawali Pers. 